\title{
PROGRESSIVE INTERVIEW LEARNING MODEL AS INNOVATION IN IMPROVING STUDENTS' LITERACY
}

\author{
Maryam, S. \\ Indonesian Language Education Department, Faculty of Teacher Training and \\ Education \\ Suryakancana University \\ Cianjur, Indonesia \\ maryamdukuh179@gmail.com
}

\begin{abstract}
This study aims to create a learning model that able to improve students' literacy skills. Within the research method development, the Progressive Interview Learning Model (PILM) has been refined and empowered continuously so the students are gradually treated in the lectures. This study used a total sample, i.e. students who take the Sociolinguistics course. Students are given experience in a structured group. The sample follows lectures with Progressive Interview Learning Model in the classroom, around the campus, and within the community. In the classroom, the interview activity is conducted to college friends about a free topic. In the campus environment, the interview is conducted to structural officials, lecturers, educational staff, and other staff with the topic of information about the lecture smoothness. While in the community, students conduct interviews with community leaders about leadership on religious, economic, security, cultural, social, educational, and community topics. The results showed that students' literacy ability increased significantly. The implication for literacy teacher can be integrated with four language skill in learning.
\end{abstract}

Keywords: learning model, literacy competence, progressive interview, language proficiency.

\section{INTRODUCTION}

This research was based on the importance of literacy competence. Interview as a language skill would be explored in this research. An interview must have a questioning skill. In fact, the ability to ask is still low (Nuraini, 2017). Many studies have been corroboratethis finding. Previously, Beaver and Tuck (1998) finds that the difference between the magnetic and the differences between the ethnic groups; However, women are more likely to approach questions about their competence in English and learning cultured.Sitthisak and Gilbert (2010) sought to develop the ability to elaborate questions and test learners' knowledge. Ontological databases are used to store a sequence of questions, materials and learning outcomes.

Banyuwangi reading house has one important principle, "no asking before reading" This principle can be used to motivate the people in increasing their literacy competence.

Adi, et al (2017) investigated the effect of STAD treatment on reading comprehension in students of grade XI SMAN 1 Kediri Tabanan in academic year 2013/2014. Maryam, et al (2013), also found the lack of reading activity on the literature text. Sumiani (2014) conducted a study that integrates interview activities, writing and narrating the interview results.Permanasari (2014) found the reason that students of vocational schools should be able to communicate orally andthe three steps interview method is applied to improve students' ability in speaking English.

Nowadays, isn't it necessary to have students who are able to think critically to provide solutions for development? A student is considered able to think critically if the student has a high-level understanding of the reading material. The benefit of the existence of critical thinking students will have logical implications on the lecture system and the conducive campus life, such as lecturing activity, lecture materials 
developing, media selection, various field assignment, and also intensity and quality of the relationship between lecturers and students.

Why should people increase their literacy competence?Sari and Pujiono (2017) studied literacy in the field of student reading and writing. Students read because happy only $11 \%$, while $60 \%$ read because of the task. To write, there is in the range of $17 \%$ $40 \%$. Students who associate reading and writing activities have $53 \%$. The lack of optimal literacy activities is due to constraints both internally and externally.

Programme for International Students Assessment (PISA)is a three yearsprogram (2000. 2003. 2006. 2009, 2012, and 2015) that investigate15 years old students' ability on their reading literacy, mathematics literacy, and science literacy.Indonesian teenagers rank is far from good. In the last two PISA assessment in 2012 and 2015, Indonesian'srank is the last and the last 9.

In PISA, literacy coverage is based on the lesson. While Clay and Ferguson (Hamid, 2016) has a different opinion and defines it as follow:

- Early Literacy, it covers listening, understand spoken language, and communicate through pictures and orallyformed by his experience of interacting with his social environment athome.

- Basic Literacy, it covers listening, speaking, reading, and counting

- Library Literacy, it covers the next level of literacy to optimize the literacy library. It means, the understanding of the library as an access to get information.

- Media Literacy, it covers the ability to know different types of media, such as print, electronics, and digital, and how to use them.

- Technology Literacy, it covers the ability to understand the hardware, software, and ethics in technology usage.

- Visual Literacy, it covers the advanced level of media and technology literacy, it develops the learning needs by using visual and audio-visual material critically and in respectfully.

This research is closely related to the reading literacy as well as the other five literacies above.

Literacy study is becoming widespread. At first, literacy only refers to reading activity but nowadays, it is more varied. Science and technology development affects literacy field progression. There are other types of literacy in 21st-century competency which is summarized in Nasir (2015) as shown below.

Table 1. 21st-century competence

\begin{tabular}{|c|c|c|}
\hline $\begin{array}{l}\text { Learning and Innovation } \\
\text { (the } 4 C^{\prime} \text { 's) }\end{array}$ & Digital Literacy & Career and Life \\
\hline 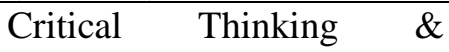 & Information Literacy & Flexibility and Adaptability \\
\hline \multicolumn{3}{|l|}{ Problem Solving } \\
\hline Creativity and Innovation & Media Literacy & Initiative and Self-direction \\
\hline Communication & ICT Literacy & $\begin{array}{l}\text { Social and Cross-cultural } \\
\text { Interaction }\end{array}$ \\
\hline \multirow[t]{3}{*}{ Collaboration } & & Productivity \\
\hline & & $\begin{array}{l}\text { Accountability } \\
\text { Leadershin }\end{array}$ \\
\hline & & Responsibility \\
\hline
\end{tabular}


From the table above, it can be seen that literacy is connected to digital. It means that academically, every citizen should have digital literacy as one of the required competence at the 21 st century. At this century, there has bee a shift from conventional to digital. To reach it there are some steps to be conducted.

Regard to the 4'C, specifically communication, Sunardi (2016) affirms that a person is consideredcommunicate effectively if they are able to communicate the ideas in various forms and contexts for a broad purpose and through various media and technology. Which means, communication nowadays closely related to digital literacy which includes three types, information literacy, media literacy, and ICT literacy.

Dell Hymes's SPEAKING concept puts emphasis that the communication's implementation must be adjusted to the demands. SPEAKING is the abbreviation for situation (setting and scene), participants, purpose (ends), the form and content (act sequence), intonation (key), spoken or written (instrumentalities), interaction norm (norm of interaction and interpretation), register (genre) (Chaer and Agustine, 2010: 48).

A good resultscomes from a good process. As well, the mastery of the competencies. The problem is how to develop a progressive interview learning model that can develop literacy competence? While the complaints about students are not able to ask and students not able to read still not subsided. That conditions, according to results of some study, one of them is Farida (2012) that found the low rate of students' interest in reading that came form 1) lecture tasks do not require the students to read more, 2) library does not have an adequate collection of titles or numbers; 3) reading is not a students' culture, 4) students have to vary activities to keep them busy, 5) embarrassment of being mocked by friends. The most dominant factor is the internal factor which comes from within the students itself.

Based on that, this study aims to design an innovative learning model. Joyce, Weil, and Calhoun (2000:6)confirms thatmodels of teaching are really models of learning. we also teach them how to learn as we helpto acquire information, ideas, skills, values, a way of thinking, and means of expressing themselves.

The model which seeks to integrate between written and spoken literacy also able to empower the students optimally so that literacy activities is not only as the facilitator but also as the initiator.

Whereas, in relation to design learning models, this study refers to the learning model of Trianto (2011). The consideration is that the design of the model combinesthe reading and speaking skill. The designed model includes learning management, evaluation system, and reaction.

The theme selection orientation is based on the current aspect (update) in addition to referral of the standard of content, standard of process, and other standards. Moreover, it also contains the values of the state's philosophy, unity and association, and diversity. Learning management and system refer to teaching principles. Then, the reaction is the set of elements or personal responses involved in this study.

The description above is relevant to the opinion of Brown (2007) who stated that learning is an experience of acquiring knowledge, either through reading, observing and experimenting both consciously and planned. Learning also 
interpreted as the process of the behavioral changes and the ability through continuous practices.

This article presented progressive interview learning model as an innovation in improving student's literacy skills. In this case, the research of learning model to improve learning outcomes have been done a lot, for instance, Wahyuni and Badriyah (2015) succeed in using think pair share method to improve the reading skill on narrative text of the students of MTsnKunirBlitar. Previously, Maryani (2011) uses discussion technic in similar research. Maryam (2007) develops linguistic creativity in essay writing by using two models, which are integrating 1) Practical Inquiry and Synectics/ Inkuiri Praktis dan Synectics (IPSY), and 2) Practical Inquiry with Keywords/ Inkuiri Praktis dengan Kata Kunci (IPCI).

In this study, the student's greatest experience was to conduct progressive interviews. Called progressive because the interview is done in stages both from the context and contents aspects. Interviews conducted at the time that were basically a refinement of previous interviews. Finally, students should prepare questions to be asked to a resource person about leadership. In local wisdom, Sundanese has known ideal leadership (Sudaryat, 2016):cageur (healthy), bageur (kind), bener (true), pinter (smart), and singer (skill). Based on the above description, this study has a hypothesis that PILM has an effect on the average difference between pretest and posttest. Its mean, higher average posttest caused by PILM.

\section{METHOD}

This research adopts research and development methods (Sukmadinata, 2011: 167). In its implementation, several methods are used, those are descriptive, evaluative, and experimental methods. The descriptive research method is applied in the initial research to collect the data of the actual conditions. This research describes the initial condition of students' literacy. The evaluative method is used to evaluate the experimental process of certain product development, not only process but also product. Based on findings in this activity, the finishing process of the product is conducted. This research is implemented to Sociolinguistic students Indonesian LanguageEducational Department odd semester 2016/2017. It means the sample is not randomly chosen, totally 49 students of the fourth semester.Interview conducted in groups so that there are duties as interviewer, recorder, and so fits with the needs.

This research used several instruments, namely the design of learning models, questionnaires, observation sheets, interview gratings, and performance tests. All instruments are used to get data. The study expects if the answers are expected to be explanatory. We got broad information from the resource.Student as an interviewer should be focused on the resource person's answers because they have to transcript the spoken language to written form which equipped with a picture attachment. The picture is used as an accurate physical evidence to guarantee the originality. Besides, students are required to be able to conclude the interview result. In the last stage, students required to report the interview video.Observation and evaluation were conducted intensively to maintain the validity of this study.

Relevant with the purpose of this study, which is to create a Progressive Interview Learning Model (PILM) in order to improve literacy competencies. The 
question is, "How to create PILM in the development research?" To answer the question, this study refers to Sukmadinata (2011) which provides guidance for the development research. The research stage is modified 10 research steps and it is developedby Gall and Borg to three steps, namely 1) introduction that includes needs analysis, literature review, and studying the existing models, 2) implementation of product development, starts from designing PILM as draft, revising, and several times testing; 3) product evaluation and validation, both process, and outcome. Those three-modified-stages are modified in this research as shown in the figure below.

Figure 1. Research Stages of Research and Development of Progressive Interview Learning Model

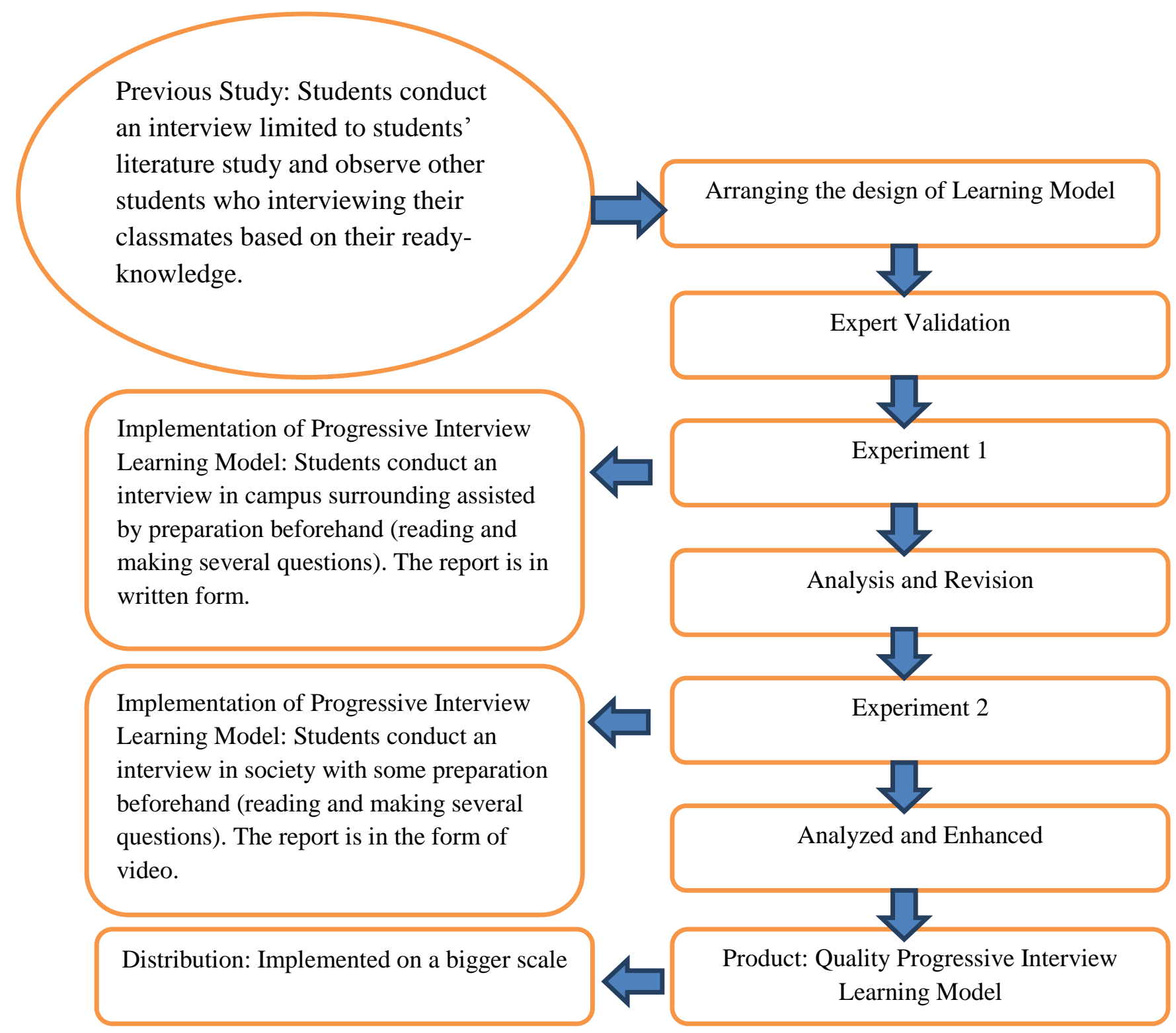




\section{FINDINGS AND DISCUSSION}

First, the study got the result from the questionnaire, observation, and interview in previous research. Data related to the initial condition of students' literacy.Fromthis data, we able toconduct identification needsanalysis. Preliminary data are detailed as follows:

1) supports the profile of the host or master of ceremony.

2) In Sociolinguistics syllabus, there was a development of speech competence events, including reporting the use of spoken language, and making transcripts of interview results.

3) By observing we found that the learning process was dominated by the student chapter reports while the student participation was still low, in askingquestions, refuting, or adding answers.

Response students to the low literacy activities

The preliminary study results are used as input material for the model design. Prior to designing the model, along with the results of the analysis, there are processes as follow: read the various sources of theory, the results of previous research, teaching principles, material analysis, task analysis, objective analysis, and media learning.

The second we have the evaluative method resultthat is used to evaluate the experimental process of certain product development. Learning design is referred to Trianto (2011) concerning the Integrated Learning Model. The reason for choosing this model as the base is that this learning model combines the skills of spoken and written language.

Below we describe the developed improvement interview learning models that is designed with the aim of providing interviewing skills to students. Interviews should be conducted based on knowledge. Therefore, before the interview students are required to read the topic of the interview, either from books or internet. In this model, interview activities must be supported by reading activities so that it becomes a blend of oral language activity with written language. The implementation models describes as follows in the table below.

Table 2 Development of Progressive Interview Learning Model

\begin{tabular}{clll}
\hline \multicolumn{1}{c}{ Aspect } & \multicolumn{1}{c}{ Step 1 } & \multicolumn{1}{c}{ Step 2 } & \multicolumn{1}{c}{ Step 3 } \\
\hline Design & $\begin{array}{l}\text { Creating a model } \\
\text { design based on } \\
\text { the concept of } \\
\text { integrated } \\
\text { learning: themes, } \\
\text { management, } \\
\text { evaluation, and } \\
\text { reactions }\end{array}$ & $\begin{array}{l}\text { Create a model design } \\
\text { based on integrated } \\
\text { learning concepts: } \\
\text { objectives, themes, } \\
\text { management, } \\
\text { evaluation, and } \\
\text { reactions }\end{array}$ & $\begin{array}{l}\text { Create a model design } \\
\text { based on integrated } \\
\text { learning concepts: } \\
\text { objectives, themes, } \\
\text { management, evaluation, } \\
\text { reactions, Internet-based } \\
\text { learning, and products. }\end{array}$ \\
\hline Theme & $\begin{array}{l}\text { Free to the } \\
\text { students (research }\end{array}$ & $\begin{array}{l}\text { Campus community } \\
\text { activities (matters } \\
\text { relating to the fluency } \\
\text { of lectures) }\end{array}$ & $\begin{array}{l}\text { Leadership in } \\
\text { perspective culture: } \\
\text { cageur (healthy), } \\
\text { bageur (kind), bener } \\
\text { (true), pinter (smart), }\end{array}$ \\
\hline
\end{tabular}




\begin{tabular}{|c|c|c|c|}
\hline \multirow{2}{*}{$\begin{array}{l}\text { Model } \\
\text { Stages }\end{array}$} & & & and singer (skill). \\
\hline & $\begin{array}{l}\text { 1. Apperception } \\
\text { that contains the } \\
\text { introduction of } \\
\text { student profiles } \\
\text { to other } \\
\text { students. } \\
\text { 2. To complete } \\
\text { the profile, } \\
\text { students } \\
\text { interview } \\
\text { students who } \\
\text { want to know } \\
\text { more in the } \\
\text { class. } \\
\text { 3. Students report } \\
\text { the results of the } \\
\text { interview } \\
\text { verbally. } \\
\text { 4. After attending } \\
\text { the presentation, } \\
\text { other students } \\
\text { respond. } \\
\text { 5. Direct lecturers } \\
\text { convey their } \\
\text { judgments on } \\
\text { student } \\
\text { performance } \\
\text { while observers } \\
\text { record the } \\
\text { quality of the } \\
\text { learning } \\
\text { process. }\end{array}$ & $\begin{array}{l}\text { 1. Apperception that } \\
\text { contains the } \\
\text { introduction of } \\
\text { student profiles to } \\
\text { other students. } \\
\text { 2. To complete the } \\
\text { profile, students } \\
\text { interview students } \\
\text { who want to know } \\
\text { more in the class. } \\
\text { 3. Students report the } \\
\text { results of the } \\
\text { interview verbally. } \\
\text { 4. After attending the } \\
\text { presentation, other } \\
\text { students, lecturers, } \\
\text { observers are given } \\
\text { the opportunity to } \\
\text { respond. } \\
\text { 5. Positive responses } \\
\text { are smaller in } \\
\text { frequency than the } \\
\text { negative responses } \\
\text { of these three } \\
\text { elements. } \\
\text { 6. Students are } \\
\text { assigned to read to } \\
\text { the library to get the } \\
\text { materials and } \\
\text { interviews. } \\
\text { 7. Interview resumed } \\
\text { outside the } \\
\text { classroom, ie in the } \\
\text { campus environment } \\
\text { jonvey their } \\
\text { of students to } \\
\text { student performance } \\
\text { while observers } \\
\text { record the quality of } \\
\text { sources who want to } \\
\text { be interviewed. } \\
\text { 8. Students give } \\
\text { interview reports via } \\
\text { e-mail. } \\
\text { ands on }\end{array}$ & 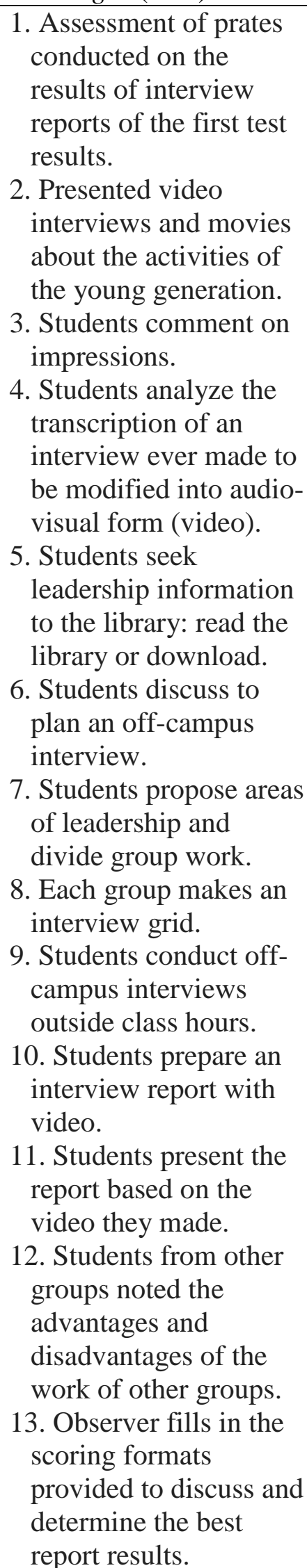 \\
\hline
\end{tabular}




\begin{tabular}{|c|c|c|c|}
\hline \multicolumn{4}{|c|}{ the learning process. } \\
\hline $\begin{array}{l}\text { Instructi } \\
\text { onal } \\
\text { Media }\end{array}$ & $\begin{array}{l}\text { This learning uses } \\
\text { media to } \\
\text { photograph, } \\
\text { record, and } \\
\text { transcribe. }\end{array}$ & $\begin{array}{l}\text { This learning uses } \\
\text { media to photograph, } \\
\text { record sound, record, } \\
\text { and transcribe. }\end{array}$ & $\begin{array}{l}\text { This learning uses the } \\
\text { media to take pictures, } \\
\text { record sounds, and } \\
\text { pictures, take notes, and } \\
\text { transcribe. }\end{array}$ \\
\hline $\begin{array}{l}\text { Evaluati } \\
\text { on }\end{array}$ & $\begin{array}{l}\text { Evaluation is } \\
\text { done on a process } \\
\text { of model } \\
\text { development and } \\
\text { student } \\
\text { performance in } \\
\text { the form of } \\
\text { interview report. }\end{array}$ & $\begin{array}{l}\text { Evaluation is done on } \\
\text { the model } \\
\text { development process } \\
\text { by matching the } \\
\text { activities of lecturers } \\
\text { and students with the } \\
\text { provided format } \\
\text { instrument and student } \\
\text { performance in the } \\
\text { form of interview } \\
\text { transcription report. }\end{array}$ & $\begin{array}{l}\text { Evaluation of model } \\
\text { development process by } \\
\text { checking the suitability } \\
\text { of lecturer and student } \\
\text { activity with instrument } \\
\text { format already provided } \\
\text { by an observer } \\
\text { Student performance in } \\
\text { the form of transcription } \\
\text { report interviews } \\
\text { accompanied by video } \\
\text { recording images. } \\
\text { Assessment is done on a } \\
\text { scale of } 1-4 \text { for aspects } \\
\text { of completeness, clarity, } \\
\text { suitability, and } \\
\text { attractiveness. }\end{array}$ \\
\hline Reaction & $\begin{array}{l}\text { Responses to } \\
\text { ideas and } \\
\text { application of } \\
\text { models from } \\
\text { observers, as well } \\
\text { as students. } \\
\text { The core of this } \\
\text { reaction is getting } \\
\text { inputs for the } \\
\text { development of } \\
\text { the learning } \\
\text { model. }\end{array}$ & $\begin{array}{l}\text { Responses to ideas } \\
\text { and application of } \\
\text { models from lecturers, } \\
\text { observers, students, } \\
\text { and resource persons. } \\
\text { The core of this } \\
\text { reaction is getting } \\
\text { inputs for the } \\
\text { development of the } \\
\text { learning model. }\end{array}$ & $\begin{array}{l}\text { Responses to ideas and } \\
\text { application of models } \\
\text { from lecturers, } \\
\text { observers, students, and } \\
\text { resource persons. } \\
\text { The core of this reaction } \\
\text { is to know the } \\
\text { acceptability of } \\
\text { development model }\end{array}$ \\
\hline
\end{tabular}

In the table above obtained three stages of development of learning model. For the purpose of hypothesis testing, We presented the results of quantitative data calculation, which is the value of the sample groups on pretest and posttest processed by using SPSS.Quantitative data on the assessment of aspects of interview reports covering aspects of clarity, completeness, attractiveness, and conformity. The data is processed with SPSS results as follows.

T-Test

Tabel 3. Paired Samples Statistics

\begin{tabular}{llrrrr}
\hline & & Mean & $\mathrm{N}$ & Std. Deviation & Std. Error Mean \\
\hline Pair 1 & Pretest & 2.9000 & 10 & .18856 & .05963 \\
& Posttest & 3.4600 & 10 & .18379 & .05812 \\
\hline
\end{tabular}


Table 4. Paired Samples Correlations

\begin{tabular}{|c|c|c|c|c|c|c|c|c|c|}
\hline \multirow{2}{*}{ Pair 1 } & \multirow{2}{*}{\multicolumn{2}{|c|}{ Pretest \& Posttes }} & $\mathrm{N}$ & \multicolumn{2}{|c|}{ Correlation } & Sig. & & & \\
\hline & & & 1 & & 385 & .272 & & & \\
\hline \multicolumn{10}{|c|}{ Paired Samples Test } \\
\hline & & \multicolumn{5}{|c|}{ Paired Differences } & \multirow[b]{6}{*}{$\mathrm{t}$} & \multirow[b]{6}{*}{$\mathrm{df}$} & \multirow{6}{*}{$\begin{array}{c}\text { Sig. } \\
(2- \\
\text { tailed } \\
\quad)\end{array}$} \\
\hline & & \multirow[b]{5}{*}{ Mean } & \multirow{5}{*}{$\begin{array}{l}\text { Std. } \\
\text { Deviation }\end{array}$} & \multirow{5}{*}{$\begin{array}{c}\text { Std. } \\
\text { Error } \\
\text { Mean }\end{array}$} & \multicolumn{2}{|c|}{$95 \%$} & & & \\
\hline & & & & & Conf & dence & & & \\
\hline & & & & & Interva & 1 of the & & & \\
\hline & & & & & Diffe & rence & & & \\
\hline & & & & & Lower & Upper & & & \\
\hline \multirow[t]{3}{*}{ Pair 1} & Pretest & & \multirow{3}{*}{.20656} & \multirow{3}{*}{.06532} & & & & & \multirow{3}{*}{.000} \\
\hline & & -56000 & & & 70776 & - & $0572^{-}$ & & \\
\hline & Posttest & . 50000 & & & $. / 0 / 70$ & $.412 \angle 4$ & $8.5 / 3$ & & \\
\hline
\end{tabular}

The calculation above can be interpreted that the average difference between pretest 2.9 and posttest 3.46 is due to the intervention or treatment of PILM. After confirmed in Table Distribution t (Arikunto, 2006: 363) at the 95\% significance level $(0.5 \%)$ with $\mathrm{db} 9$, the value of th 8.573 is greater than the tb of 1.83 . In the last table significant value $0.000<0.05$. That is, the PILM performed has an effect on the average difference between pretest and posttest. Higher average posts caused by PILM. Thus, the difference is significant. That is, the working hypothesis states that there is an average difference between before and after treatment is accepted.In addition, the acceptance of this learning model is reinforced by qualitative data obtained through questionnaires distributed before and after the sample interview.

Table 5. Student's Opinion on Interview Activities in Model

\begin{tabular}{|c|c|}
\hline Before Activities in Model & After Activities in Model \\
\hline $\begin{array}{l}\text { 1. I include stiff, do not want to shift } \\
\text { from what has been disclosed }\end{array}$ & $\begin{array}{l}\text { 1. Doing an interview means } \\
\text { preparing for a career. }\end{array}$ \\
\hline $\begin{array}{l}\text { 2. Usually, I am satisfied with the } \\
\text { existing. }\end{array}$ & $\begin{array}{l}\text { 2. I am able to conduct interviews with } \\
\text { sorted and organized questions. }\end{array}$ \\
\hline 3. A lot of time needed & 3. With interviews, we can flexibly ask \\
\hline 4. Fear of disturbing others & questions. \\
\hline $\begin{array}{l}\text { 5. Interviews are sometimes difficult to } \\
\text { find figures that are relevant with the }\end{array}$ & $\begin{array}{l}\text { 4. I love the good life so I have to ask a } \\
\text { lot }\end{array}$ \\
\hline $\begin{array}{l}\text { data we want to get so that if we are } \\
\text { not good at choosing can be the data } \\
\text { we need is not obtained or less }\end{array}$ & $\begin{array}{l}\text { 5. By interviewing, a person will be } \\
\text { able to get a lot of information that } \\
\text { is very broad and not limited }\end{array}$ \\
\hline accurat & 6. I can get along with group members \\
\hline $\begin{array}{l}\text { 6. The interview must come to the place } \\
\text { directly or must first, and we must } \\
\text { prepare the questions needed so that }\end{array}$ & $\begin{array}{l}\text { 7. Interview source is not limited } \\
\text { because it can be found anytime and } \\
\text { anywhere. }\end{array}$ \\
\hline $\begin{array}{l}\text { it does not take a lot of time the } \\
\text { character we interviewed let alone } \\
\text { the character for example very busy. }\end{array}$ & $\begin{array}{l}\text { 8. Interviews we can interact directly } \\
\text { with the community and dig the } \\
\text { information from the community }\end{array}$ \\
\hline 7. In the interview method, the results & 9. With interviews can more freely dig \\
\hline
\end{tabular}


we get just the outlines.

8. Answering an unstructured interview up the required information, by

asking a few questions.

10. If you have free time can be used to read an interview

11. Interviews that can be done anywhere will also make it easier to remember what the speakers say, although sometimes it has several versions so it is not clear the validity.

12. In the interview material obtained in accordance with what is asked to the source

13. Information obtained by interview based on the experience of the resource person.

14. Books support the writing process to be asked directly to the resource person.

15. By interview, the result/information that we want can be directly answered.

16. The material obtained through interviews is numerous, as there is freedom to ask questions

17. Through language, interviews are easily understood

18. Interviews are driven by material from various sourcebooks.

19. The material through the interview is richer than the book. Why is this so, with interviewing techniques we can directly see the objects we examine and get the information directly from those we interviewed.

20. We can know in detail

21. Jump to the person who really knows what to research.

22. We can directly know the person who will be interviewed and able to document data such as material, photos with the person who gave the information.

23. More interactive digging questions.

24. It is easier to get an answer because it is directly answered.

25. Questions and answers tend to be broader 


\section{Through interviews, it will be easier to ask whether it is material or difficulty that we seek (material) because it can be directly asked and answered, if less obvious can be asked directly}

In addition to the qualitative data above, furthermore, to know the effect on literacy, especially reading and writing, the following responses are presented.

Table 6. Student's Opinion on Reading Activities in PILM

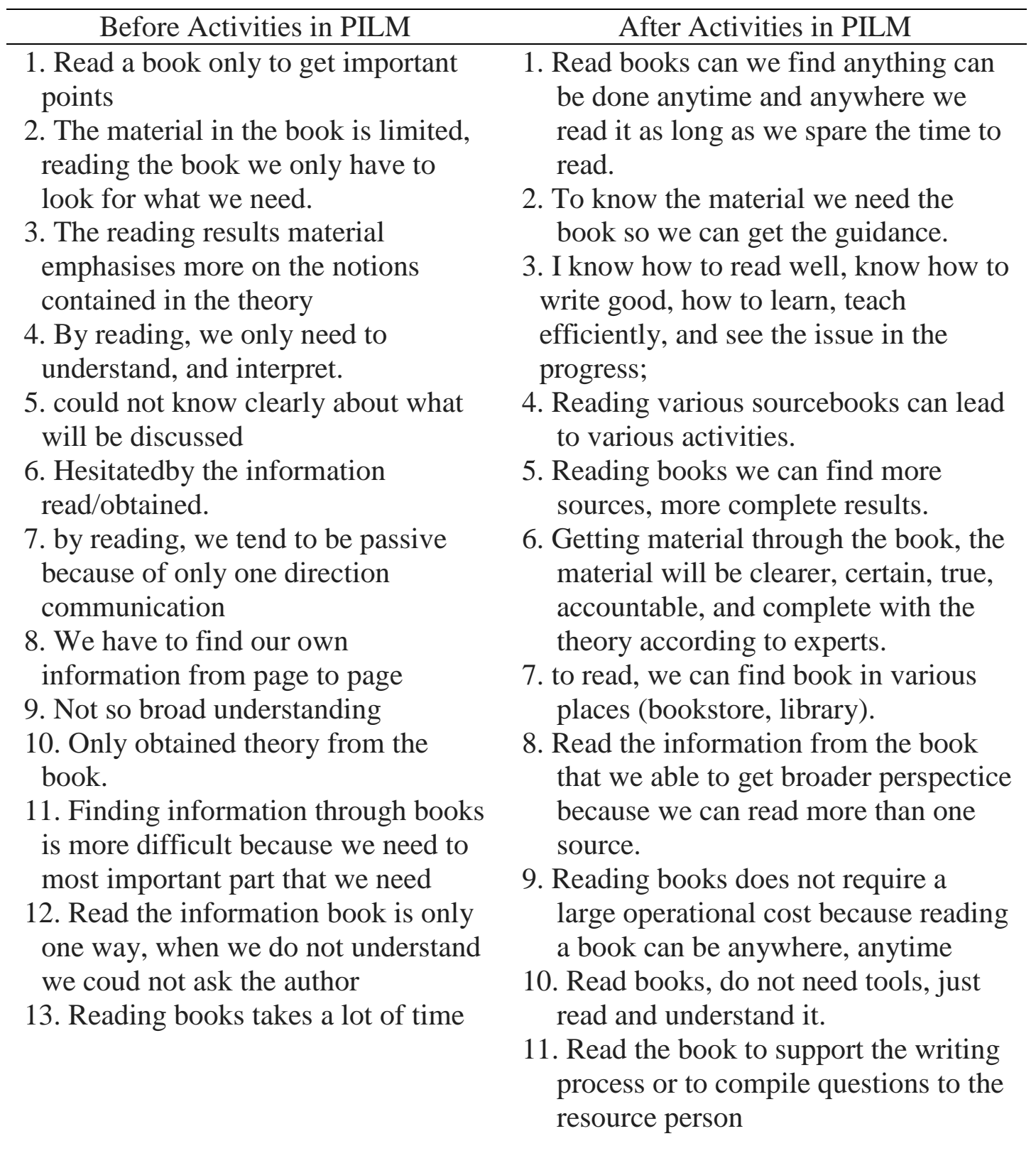


As has been said at the beginning,this study was motivated the importance of improving literacy skills that are still to be fought. The motto of BanyuwangiLiteracy Community, "never questioned if not read". The ability to ask questions in Indonesian education still needs to be improved. On the other hand, the world of talk shows in the mass media is in demand increasingly by the public. Interesting whether or not the show will rely heavily on the interviewer. Therefore it is deemed necessary to design a learning model that improves the interview ability.

Arrangement learning model that adopt from Trianto provides a four-step guidance regarding the design of learning models, which are the theme, learning management, evaluation system and response. These four elements are implemented in Progressive Interview Learning Model. Theme development conducted based on the learning principle which is simple and non-scientific to complex and scientific. Theme determination is adjusted to the place where the interview was held. The PILM development in the aspect of the place implementation is also relevant to teaching principle, from near to far. The implementation of this model is started inside the class, on campus, then in the society. The procedure of the implementation involves another lecture as the observer.

On the implementation of interview topics, students interview a classmate intended to know more about their full profiles. The theme which is there in the first draft is developed to be larger, the students interview the resource people in the campus that related to campus management or some things that needed to support the lecture. This too broad theme take a spotlight either from validator or observer, so that in the final design the theme will be specific and critical which is the leadership in local wisdom, Sundanese have been known for ideal leadership cageur (healthy), bageur (good), bener(true), pinter (smart), and singer (skilled). Students interview a figure outside the campus based on their expertise. That means the interview topic regarded as the leadership field so it's reviewed from the security, religious, cultural, economic, social, education,etcetera.

The study has a hypothesis that PILM has an effect on the average difference between pretest and posttest. Its mean, higher average postest caused by PILM. The results show that there has been a significant increase after the students follow the lecture with PILM. This increase is not accidental. The model is designed with attention to various things, including the needs of students, the world of work, progress-based lectures, both context and content aspects, the results of the lectures can be published.

Acceptance of this model, in addition to the students disclosed in Table 5 and 6 , is also accepted by observers, lecturers, experts, and validators are summarized below. The use of progressive interview learning model has several advantages, namely:

a. Students get hands-on experience

b. Student's critical thinking is more stimulated

c. Trained students learn to respect others, especially respondents

d. Trained students' learn to take full responsibility for the data they have obtained

e. Improve students' academic achievement

f. Test the students' own ideas and understanding

$\mathrm{g}$. The students are trained to manage information 
h. Increase students' motivation to literate

i. Students practice to add a broad insight

j. Learning environment varies, so learners do not feel bored.

The above statements do not indicate any rejection. Based on the results of the above research, both qualitatively and quantitatively there are several benefits of PILM. First, for lecturers or teachers, PILM can be used as an alternative model of existing models. Teachers can use the class as a laboratory to create and innovate learning so that many other learning models are created in educational institutions that are not behind desks. Is there no powerful method and media in changing learning outcomes? The experts believe only the teacher can change it.

The open nature of teachers and lecturers on the results of research is necessary because the progress of education will occur when there is openness. Quoting MacKenzie's(1970) assertion that the results of educational research do not care how good, if teachers do not want to change their paradigm it will not mean the results of the research.

For the college students, if there are any new experiences given to you in the learning process, develop it. Do not stop until the subject is done. Learn it so that can be a skill you got. Somone is known for his works.

For the researchers, there are many other aspects which have not been developed in language skill. Especially if you look at the curriculum, there are so many competencies that are mandated to be fostered and developed. The curriculum of Indonesia LanguageEducationalDepartement of FKIP Suryakancana University Cianjur accommodates many supporting profiles which ready to be developed.

\section{CONCLUSION}

PILM has three steps in the design, it covers 1) pilot study covering needs analysis, literary study, and learning the existing model; 2)implementing product, revising, and try out and, 3) evaluating and validating product; 4) From the quantitative data based on the scoring to the interview report using t-test through SPSS, it shows that there is a difference between pre-test 2,9 and posttest 3,46 because of the treatment. After it is compared to t Distribution Table (Arikunto, 2006: 363$)$ at $95 \%(0.5 \%)$ with $\mathrm{db} 9$, it shows that $\mathrm{t}_{\mathrm{h}} 8.573$ is bigger from $\mathrm{t}_{\mathrm{b}} 1.83$. Therefore, the difference is significant. It means that the working hypothesis is accepted.This means that PILM is accepted as a model and its sustainability can still be developed and used more widely.

\section{REFERENCES}

Arikunto, S. (2006). Prosedur Penelitian: Suatu Pendekatan Praktik. PT. Rineka Cipta, Jakarta.

Adi, I N. S. M., N. N. Padmadewi, N. M. Ratminingsih.(2017).The Effect of STAD UponStudents with DifferentLevel of Self

EsteemTowardReadingComprehension of EleventhGradeStudents of SMAN 1

KediriTabanan in The AcademicYear 2013/2014.International Language and Literature. https://ejournal.undiksha.ac.id/index.php/IJLL/article/view/12547. pp 158-166

Beaver, B. And Tuck, B. The Adjustment of Overseas Students at a Tertiary in New Zealand (1998). New Zealand Journal of Educational Studies, 33 (2), pp 167-179. 
Brown, H. D. (2007). Prinsip Pembelajaran dan Pengajaran Bahasa.USA: Pearson Education Inc

Chaer, A.danAgustina, L. (2010).Sosiolinguistik. Jakarta: RinekaCipta

Farida, S. Faktor-Faktor Penyebab Keengganan Membaca di Lingkungan Mahasiswa: Studi Kasus. Prosiding Seminar Nasional Bahasa 2012. Fakultas

Bahasa Universitas Widyatama http://repository.widyatama.ac.id/

Hamid, M. (2016). Desain Induk Gerakan Literasi Sekolah. Jakarta: Direktorat Jenderal Pendidikan Dasar dan Menengah Kementerian Pendidikan dan

Kebudayaan[online] http://repositori.perpustakaan.kemdikbud.go.id/39/1/ Desain-

Induk-Gerakan-Literasi-Sekolah.pdf

http://rumahliterasiku.org/Tafsir Bebas Atas Tagline "Pantang Tanya Sebelum

Baca" [Online]

http://www.pediapendidikan.com/2016/07/konsep-literasi-dan-gls.html.

http://www.indonesiapisacenter.com/2013/08/sekilas-tentang-pisa_3.html.

Maryam, S, et al.(2013).Literasi Sastra pada Mahasiswa Program Studi

Pendidikan Bahasa dan Sastra Indonesia. Atikan: Jurnal Kajian Pendidikan. 3

(2) Desember 2013.

Maryam, S.(2007). Pengembangan Kreativitas Berbahasa dalam Menulis Esai. Educasionist Journal. [online] http://file.upi.edu/Direktori/ JURNAL /EDUCATIONIST/Vol._I_No._2-Juli_2007/5_Siti_Maryam_Layout2rev.pdf. pp. 103-115.

Maryani. (2011). Peningkatan Kemampuan Mengubah Teks Wawancara Menjadi Teks Narasi Melalui Teknik Diskusi pada Siswa Kelas VII-B Sekolah Menengah Pertama Negeri 2 Gadingrejo Tahun Pelajaran 2010/2011. Skripsi. Lampung: FKIP Universitas Lampung. [Online] http://digilib.unila.ac.id/698/2/Abstrak.pdf

MacKenzie, N. (1970). Teaching and Learning. Belgium : Unesco.

Nasir, M. (2015).PengembanganMutu Modal Manusia, Kelembagaan, danInovasi.http://www.iseisby.or.id/attachments/article/181/Materi\%20MENR ISTEK.pdf. [Online]

Nuraini, F. (2007).ProfilKeterampilanBertanyaSiswapadaPembelajaranBiologi SMA Negeri 2 Bandar Lampung TahunPelajaran 2016/2017.Skripsi.http://digilib.unila.ac.id/26682/3/SKRIPSI\%20TANPA\% 20BAB\%2PEMBAHASAN.pdf

Pedoman Akademik FKIP Universitas Suryakancana Cianjur 2016/2017. Kurikulum 2016 Program Studi Pendidikan Bahasa Indonesia. Tidak Diterbitkan.

Permanasari, R.C. (2014). Improving Students' Speaking Skill Through Three Steps Interview Technique(An Action Research of the Tenth Grade Students of SMK Negeri 9 Semarang in the Academic Year of 2013/2014). Skripsi. Universitas Negeri Semarang

Sari, E. S. \& Pujiono, S. (April 2017). Budaya Literasi mahasiswa FBS UNY. LITERA Volume 16 Nomor 1, 105-113. [online] https://journal.uny.ac.id/index.php/litera/issue/view/1409

Sitthisak, O., Gilbert, L. An Evaluation of Generated Question Sequences Based on Competency Modeling. (2010) Proceedings of the 18th International Conference on Computers in Education: Enhancing and Sustaining New 
Knowledge Through the Use of Digital Technology in Education, ICCE 2010, pp. 220-227.

Sudaryat,Y.(2016). "Bahasa

SundadalamGamitanKearifanLokaldanPendidikan".Pidato Pengukuhan

Guru Besar. [Online] http://berita.upi.edu/?p=11149

Sukmadinata, N.Sy. (2011). Metode Penelitian Pendidikan.Bandung: Rosdakarya. Sumiani, N.W. (2014). PeningkatanKemampuanMengembangkanHasil

WawancaraMenjadiKaranganNaratifdenganPendekatanIntegratifSiswaKelas

VII E SMP Negeri 2 BangliTahunPelajaran 2013/2014.Skripsi. Denpasar:

UniversitasMahasaraswati. Online http://unmas-library.ac.id/wpcontent/uploads/2014/11/SKRIPSI4.pdf

Sunardi. (2016).Pengembangan 4Cs dalam Pembelajaran Matematika Sebuah Tantangan

Pengembangan Kurikulum Matematika. http://pasca.um.ac.id/wp-content/uploads

12016/09/ProsidingPendidikan Matematika Pasca UM2016.pdf

Trianto.(2011). ModelPembelajaranTerpadu. Jakarta: BumiAksara.

Wahyuni, S. and Badriyah, L. (2015). Using ThinkPair Share Method to ImproveThe ReadingSkill on NarrativeText of The Students of MTsnKunirBlitar. Jurnal RealitaVol. 13 No. 1 Januari 2015 | 97-111 [Online] http://download.portalgaruda.org/article.php?article 